\title{
The Current Status of Mongolia's Museums: Changes Taking Place in the Practical Activities of Museums Since the 1990s
}

\author{
Ichinkhorloo Lkhagvasuren
}

\begin{abstract}
From the middle of 1920s to the 1990s, the museum affairs of Mongolia were dominated by communist-socialist ideology, demolishing the culture of the exploiter class and creating the culture of the exploited class. The democratic movement since the 1990s brought a big change in the field of culture, particularly for the protection and conservation of historic and cultural heritage, and for the museum activities. It was necessary to improve working conditions in museums, train professional staff, and to participate in international cooperation between museums. New museums were set up as to replace dissolved museums, and other museums were established anew including those under private ownership. Mongolia's museums have achieved much in the implementation of their goals, but much remains to be accomplished.
\end{abstract}

\section{Particulars of Museum Activities in Mongolia Prior to the Period of the Democratic Movement}

With the victory of the People's Revolution in 1921, a new period of development started in the political and social spheres of Mongolia. In November of 1921, the People's Government issued a resolution to start preparations for the establishment of a museum within the structure of the Institute of Sutras and Scripts (currently, the Academy of Sciences). The Institute of Sutras and Scripts immediately started implementing this important decision of the Government of Mongolia. First of all, the Institute of Sutras and Scripts issued an official request to the chanceries of aimags (khanates) and khoshuuns (banners), by which they ordered the sending to the institute of information relating to historic and cultural artefacts and interesting things that was available or known in their local areas and territories. In addition, researchers from the Institute of Sutras and Scripts started working in rural areas

\footnotetext{
I. Lkhagvasuren $(\bowtie)$

Mongolian National University of Science and Technology,

Baga Toiruu -34, SHUTIS building -2, Ulaanbaatar 210646, Mongolia

e-mail: suren_san@yahoo.com 
and local territories to collect exhibits for the museum. This way, collection of museum exhibits started in Mongolia. As a result of intensive work conducted by the Institute of Sutras and Scripts in the collection of older books and sutras in the rural countryside, 2100 books in foreign languages, 600 older books and sutras in the Mongolian language, 250 books and sutras in the Tibetan language, and about 1400 books and sutras in the Japanese and Manchu languages were collected (Sereeter et al. 2003: 30). In 1924, the People's Government approved the "Rules for the Protection and Conservation of Antiques." This document was the first legal act for the protection and conservation of historic and cultural artefacts, and for the conducting of museum activities. Upon the approval of this legal act, many achievements have been made in respect of finding items with museum significance, registering those items at an archive of the museum, documenting and organizing preservation and conservation activities, and conducting researches of and putting items of the museum into scientific circulation. However, the Institute of Sutras and Scripts that was set up anew at that time encountered a number of challenges including lack of experience managing museum works, limited possibilities regarding registration and documentation of museum artefacts and pieces, lack of museum buildings that were specially fit for preservation and conservation of museum items, and lack of professional employees.

To overcome the above obstacles, the signing of an agreement between the Institute of Sutras and Scripts and the Russian Academy of Sciences was an event of important significance. With this agreement starting 1923, it became possible to work in Mongolia for the Mongolia and Tibetan Research Unit organized by the Russian Academy of Sciences. This research group was led by a noted Mongolia studies scholar and among the participants were A. D. Simukov and V. I. Lisovskii who later became renowned scholars of Mongol studies (Konagaya et al. 2007: 51). The research unit while working in Mongolia for over a period of 3 years actively participated in the preparations for setting up a first museum in Mongolia, collecting museum artefacts, registering and documenting museum items, organizing preservation and conservation, and providing museum employees with practice and experience of museum works (Konagaya et al. 2008: 89). The research group led by P.K. Kozlov conducted an archeological excavation at Noyon Uuul (150 km northeast of Ulaanbaatar) and found a number of interesting findings relating to economics, as well as artefacts with material and cultural significance of the early Khunnus. The archaeological excavation at Noyon Uul and the findings there created a real sensation among the world scientific community at that time. A temporary exhibition, with findings of this archeological excavation at that time, was like a new page in the cultural life of Mongolia. Currently, most of the findings are kept in the storage facility of the State Hermitage in Saint Petersburg of the Russian Federation. A few of them are kept at the National Museum of Mongolia. Around the time when the P.K. Kozlov led research group worked in Mongolia in May 1925, a cooperation agreement was signed between the Institute of Sutras and Scripts and the American Museum of Natural History. With the signing of this agreement, it became possible for the third Asian expedition led by Roy Chapman Andrews, American scholar and Central Asian student, to work in southern Gobi. 
Fig. 1 O. Jamiyan,

Chairman of the Institute of Sutras and Scripts and of the museum

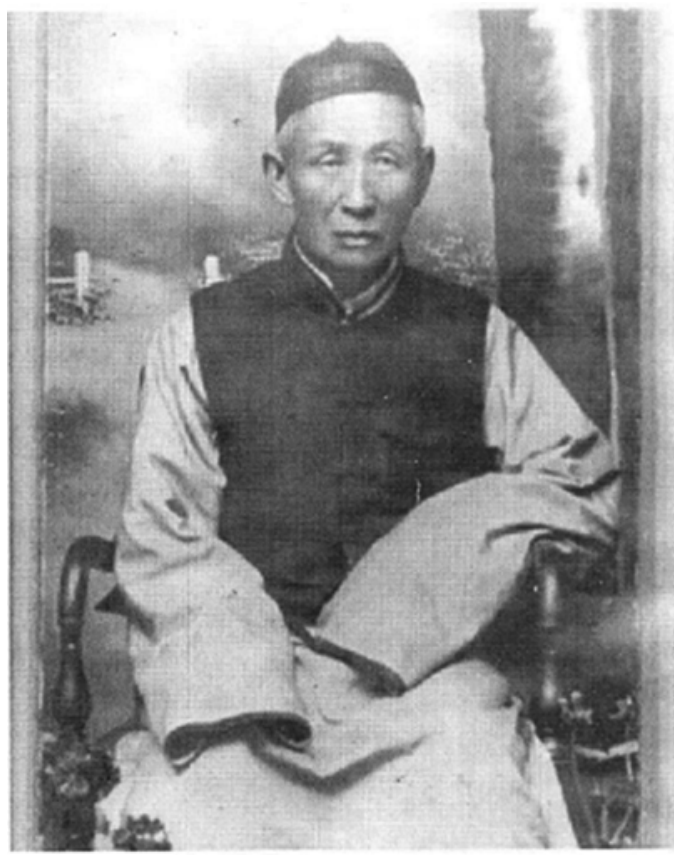

This research unit had excavated an area named Erin Davst located near the Gobi Gurvan Saikhan Mountains of Umnugobi Aimag and found a number of very rare findings in large quantities. This excavation caused a great stir among the world scientific community at that time. In accordance with the agreement signed with the Institute of Sutras and Scripts, this research unit left most of its findings in Mongolia. Currently, these very rare findings are kept in the storage facility of the Mongolia Natural History Museum. However, this research unit led by R.C. Andrews took with them a number of its findings without leaving them in Mongolia (Tsendsuren 2014: 29). Currently, these findings are kept in the storage facility of the Natural History Museum in New York.

These measures organized by the Institute of Sutras and Scripts in the mid-1920s were of great importance in the establishment of a museum in Mongolia. Thus, a first modern day of exhibition started in Mongolia on December 25, 1924. At the beginning, O. Jamiyan (Fig. 1), chairman of the Institute of Sutras and Scripts, cochaired the museum. The People's Government on April 1, 1926 decided to transfer the Palace and goods and items utilized by VIII Bogd Javzandamba Khutgat to the possession of the museum. In the period of 1929-1930, confiscation of feudal property, goods, and items having museum significance was organized as the largest political campaign and these were during this period transferred to the museum stores. Owing to these measures, the newly set up stores of the museum were enriched with a great number of artefacts and items of museum significance.

However, the large-scale political campaigns that progressed in Mongolia from the middle of the 1920 s showed a greater negative impact on the activities for pres- 
ervation and conservation of historical and cultural memorial items. The Third Congress of the Mongolian People's Revolutionary Party (MPRP) took place in 1924. The MPRP was the sole governing political force at that time. All issues relating to politics, economics, and social life were fully determined by the policy and decision of this party. The Third Congress of the MPRP approved a document that went into history as the "Party's Course Line" (Lkhamsuren 1985: 53). This document determined the future developmental direction of Mongolia as a "non-bourgeois development path." It was the beginning of domination and rule of communistsocialist ideology in Mongolia. What is communist-socialist ideology? It is worth giving a few words regarding this ideology. Since the creation of private property, human society has been divided into two antagonist classes called the "exploiter class" and the "exploited class." An unreconcilable struggle has been taking place between these two classes. Karl Marx, founder of Marxist thought, wrote that the history of humanity is the history of class struggle. Culture is also differentiated into the "culture of the exploiter class" and the "culture of the exploited class." In terms of content and form, the culture of the exploiter class and the culture of the exploited class cannot be reconciled with each other. The culture of the exploiter class has always protected the interests of the exploiter class. Because the culture of the exploiter class will interfere and hamper the construction of a new society, it should be demolished. Instead, a new culture that protects the interests of the exploited class should be created. This is one of the main goals of socialist revolution. Destruction of the culture of the exploiter class, creation of a new socialist culture that protects the interests of exploited class and that expresses its worldview, and creation of a new socialist culture can be attained only through a cultural revolution. Therefore, any country that aims to create and establish a socialist society must necessarily implement a cultural revolution. Founders of the Marxist-Leninist doctrine teach that without cultural revolution, it is not possible to build rightful prospects for humanity, that is, a communist and socialist society. This is the main idea of communist-socialist ideology. Following the Third MPRP Congress, the immediate start was to implement its decision in actuality. Starting at this time, the cultural heritage of the Mongolian people, which had been created by many generations, was treated as the culture of the exploiter class and the culture of the exploited class in accordance with communist-socialist ideology. Thus, a cultural revolution started in Mongolia. Beginning this time, wearing of national clothes and use of decorations made of gold and silver were banned. In addition, Buddhist activities began to be banned. By the middle of the 1930s, large campaigns were organized against Buddhism; during this period, many hundreds of temples and monasteries were demolished and burned and senior monks were executed. Also, a number of historic themes, for instance, the history of the Great Mongol Empire, the history of the Golden Horde, and the "Golden Kinship" of Chinggis Khan, were banned from undergoing any research work. Studies in the above research fields must be made and examined as well as evaluated from the position of Marxist-Leninist teachings. Any kind of advocacy (a literary work, movie, drama, song, poem, fine art, museum exhibition, etc.) in the above themes was banned. No preservation or storing in museum stores was allowed for productions and works from the culture of the exploiter class. There was the trend 
that works from the culture of the exploiter class were not considered as cultural heritage. This way, it opened the channel to losing the cultural products created by the Mongols, and many historical and cultural heritages created by many generations of Mongol nomads began their passage over the Mongolian border. Many historical and cultural heritages that illegally left this country at that time are currently kept in the museums of European countries such as Britain, France, Finland, Denmark, Austria, Sweden, and Russia (Konagaya and Lkhagvasuren 2014: 76). The authority of communist-socialist ideology in Mongolia continued up to the 1990s. As dictated by this ideology, the main directions of museum activities in Mongolia dealt with the praising of social revolution and socialist society being built anew. Clear examples of museums with communist-socialist ideology were the Lenin Museum and the Museum of Revolution, established with the investment of many millions in the Mongolian national currency - the tugri- of the state budget. The Lenin Museum, which did not have even a single original exhibit, had forced visits by many dozens of persons each year. Even now, Mongolia is not fully rid of the influences of this ideology. In particular, the impact of communist-socialist ideology still clings tenaciously to the life of cultural and museum affairs.

\section{Changes and Innovations That Started in the Museum Field}

At the beginning of the 1990s, Mongolia had about 50 museums with the status of "state museum," "local country museum," and "specialized museum," and over 200 museums with the status of "local country study chamber" (Fig. 2). They house over

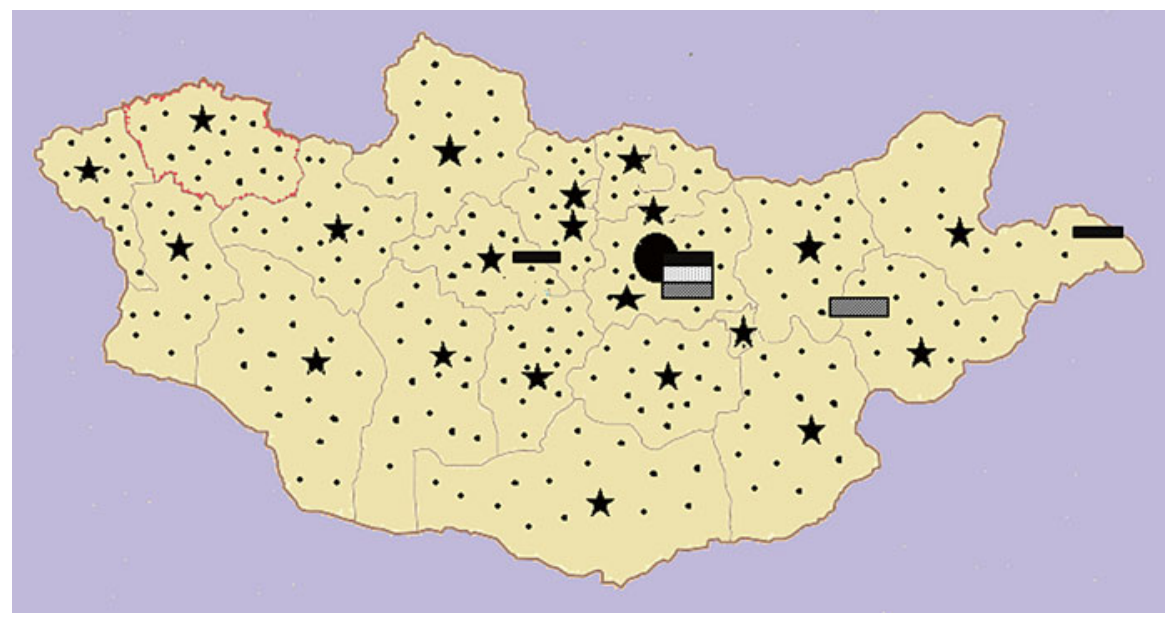

Fig. 2 Map of Mongolian museums (2015): local country study chambers (•), local country museums $(\star)$, state museums ( , specialized museums ( ) and the Authority for Museums (ZZZ), Ulaanbaatar capital ( 
a total of 270 thousand museum pieces and artefacts. There were no privately owned museums in Mongolia at that time. The Authority for Museums under the Ministry of Culture managed the activities for state and local country museums (Burnee 1994: 32).

The democratic movement has spread in Mongolia since the 1990s, and the larger changes were brought about in the field of culture, particularly the preservation and conservation of historic and cultural objects as well as in the activities of museums. First of all, the activities of museums needed to be freed from the influences of communist-socialist ideology. The aim of activities of museums was to find historical and cultural objects, register such objects into the museum collections, organize works for the preservation and conservation of museum objects, draw these objects into the cycle of scientific research, and promote public advocacy of museum goals. It was required to improve the working conditions in museums (i.e., setting up special buildings for museums), to innovate the equipment and furniture of currently operating museums, and to prepare professionals for the museums. In addition, it was required to actively participate in international cooperation between museums, and to expand the former international relations that were restricted only to the museums of socialist countries. In contrast, it was required to establish direct contact with many museums of other nations. Another goal put forward during this period was the creation of possibilities for setting up museums under private ownership. In order to implement these goals, it was required to take many measures in due order while not losing time.

In order to implement all of these works, the new democratic government started its job by the dismissal of the Authority for Museums in 1992. The Authority for Museums under the Ministry of Culture was in the first place created in order to coordinate activities for the state and local country museums. However, with time, this institution had gained strong control over the activities of museums by exercising communist-socialist ideology and made museums lose their autonomy and created a great number of obstacles in their activities. People were strongly critical of the functions of this institution and urged for its dismissal. With the dissolution of the Authority for Museums, the Ministry of Culture started conducting direct management of museum activities.

The second important decision implemented by the Ministry of Culture was the dismissal of some museums established in the first place in harmony with communist-socialist ideology. Within the frame of work, in the first order, the Museum of Revolution, State Central Museum, and Lenin Museum were targets for dismissal. In respect of the Lenin Museum, without the status of state museum, it functioned under the affiliation of the MPRP-the governing political party at that time. At the beginning of 1991, the Steering Council of the MPRP requested the Ministry of Culture to accord the status of state museum to the Lenin Museum, and to change its affiliation status from the MPRP to the Ministry of Culture. However, the Ministry of Culture gave a negative reply to this request. As to the replacement of dissolved museums, the Ministry of Culture decided to establish the Museum of Natural History (1991) and Museum of National History (1991). In addition, it was decided to establish a number of museums anew that include the Fine Arts Gallery 


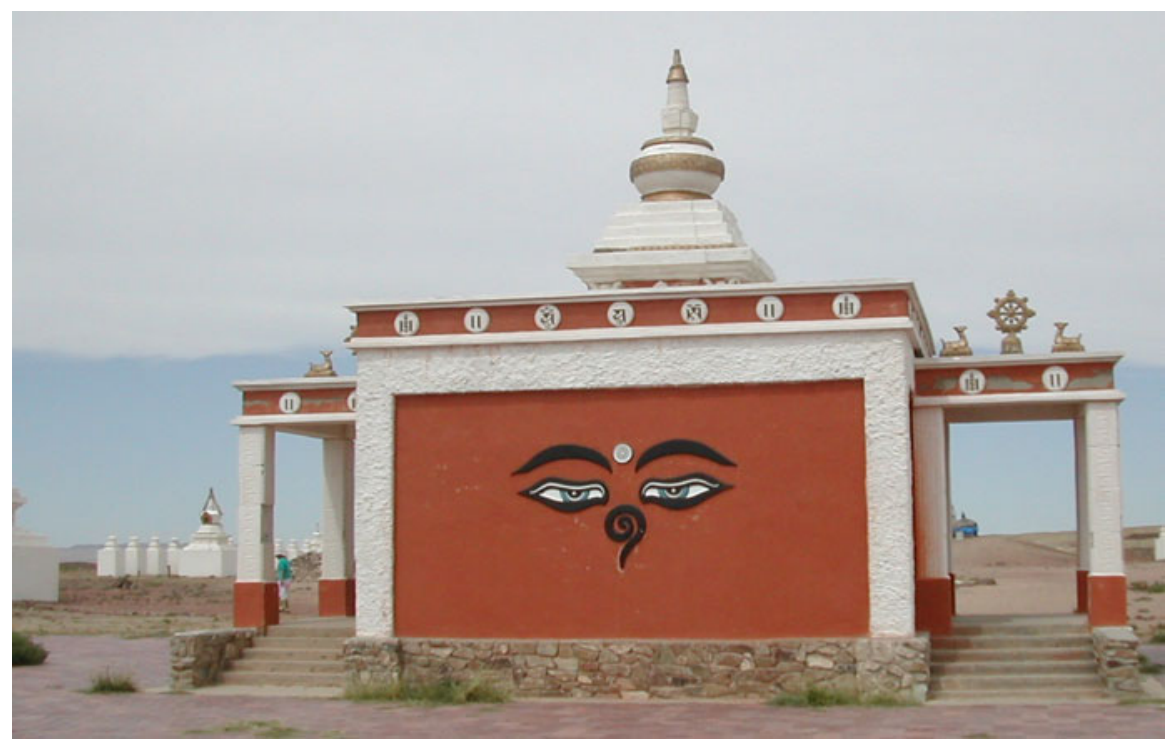

Fig. 3 Museum of Noyon Khutagtu

(1991), Museum of Theatre Arts (1991), and Museum of Choijin Lama Temple (2000). Later on, the Museum of Kharakhorum (2009) and Museum of Khushuu Tsaidam (2010) were also set up anew. A decision to establish the Museum of Dinosaurs was issued in 2013 and preparatory works are currently underway.

Since the 1990s, the goal of establishing museums under private ownership started for the first time in Mongolia. Currently, a number of museums under private ownership are conducting their activities. These include the Museum of International Intellectuality, Museum of Noyon Khutagtu (1991) (Fig. 3), and Museum of the Heritage of Chinggis Khan (2006).

\subsection{The Museum of Natural History}

With the dissolution of the State Central Museum in 1991, to replace it, it was decided to set up a Museum of Natural History. The State Central Museum was first established in 1956 and consisted of two sections: the Natural History Section and the History and Ethnicity Section. By the way of expanding its Natural History Section, an independent Museum of Natural History was established. A collection of exhibits for the Natural History Section had already started from the middle of the 1920s. The very rare paleontological findings by the third Asian expedition led by R. Chapman Andrews, American scholar and researcher on Central Asia, findings of flora and fauna, minerals, items, and museum pieces, themed naturalistically and collected by the researchers of Institute of Sutras and Scripts, were housed 


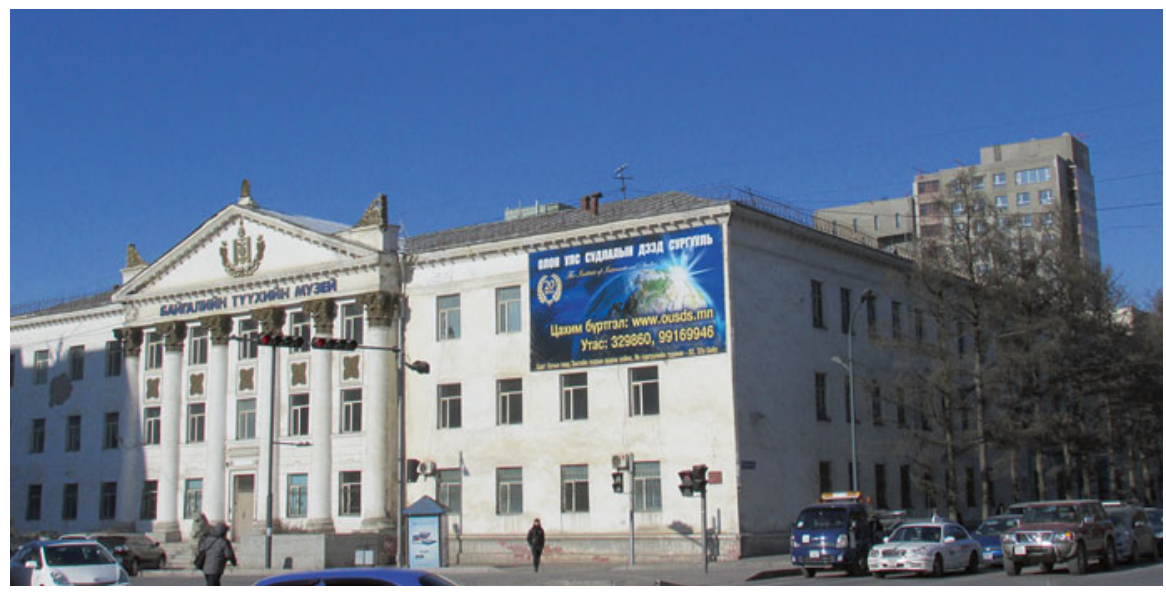

Fig. 4 The Museum of Natural History

in this museum. In 1991, when the State Central Museum was dissolved, its Natural History Section was storing over 8,000 museum pieces and artifacts.

The newly set up Museum of Natural History made large changes in the ways of displaying museum exhibits and in the way of arranging the museum halls. Prior to the 1990s, photos were mainly used as exhibits in the planning of museum halls, and original objects and exhibits were rarely used. The newly established Museum of Natural History aimed to use predominately original objects and museum pieces in the arrangement of exhibits in the museum halls. Currently, the museum halls are divided into eight main themes: (1) Hall of Physical Geography of Mongolia; (2) Hall of Geology and Mineral Resources of Mongolia; (3) Hall of Birds of Mongolia; (4) Hall of Flora of Mongolia; (5) Hall of Insects and Amphibians; (6) Mammals of Mongolia; (7) Hall of Paleontology; and (8) Hall of Human Origins. About $37 \%$ of all collections are shown as exhibits in the halls of the museum (Myandas 2014: 287).

Currently, this museum is conducting its activities in the building of the State Central Museum that was dissolved earlier (Fig. 4). This building was first built as a special professional school in 1954. The State Central Museum has been functioning in the same building since its opening in 1956 and until its dissolution in 1991.

\subsection{The National Museum of Mongolia}

With the dissolution of the Museum of Revolution in 1991, it was replaced by the National History Museum. The History and Ethnicity Section from the dissolved State Central Museum has been joined with the Museum of Revolution and by way of such expansion, a new National History Museum was created. A collection of exhibits for the History and Ethnicity Section of the State Central Museum had already started from the1920s. The very rare and interesting collections of museum 
pieces and artifacts relating to Mongol history and ethnicity and gathered by researchers from the Institute of Sutras and Scripts were housed at this museum. In addition, some findings by the Mongol and Tibet expedition organized by the Academy of Sciences of the Russian Federation were also kept at this museum. The dissolved Museum of Revolution first established in 1971 on the occasion of the 50th anniversary of the People's Revolution presented itself as museum of pure political ideology. The museum had been working with the goal of advocating the progress of socialist construction after the victory of the 1921 People's Revolution in Mongolia, and publicizing the achievements of socialism and educating the youth to become trustworthy citizens with the ideals of communism and socialism.

In 1991, when the Museum of Revolution was dissolved, a total of 13,000 museum pieces and artifacts were kept at the museum. The newly set up Museum of National History is the first full-scale independent museum on Mongolian history and ethnicity. Prior to this, Mongolia did not have an independent museum relating to Mongolian history and ethnicity. The MPRP considered that the setting up of a full-scale and independent museum on Mongolian history and ethnicity would not conform to communist-socialist ideology. The newly established Museum of National History consisted of two sections: the Mongolian History Section and the Mongolian Ethnicity Section. This museum had completed large changes in the way of organizing the museum halls. Currently, this museum arranges its museum halls into 10 themes of Mongolian history and ethnicity: (1) Ancient Mongolia; (2) Period of Early States Created in the Territory of Mongolia; (3) Period of the Mongolian Empire; (4) Mongolia during the XVII-XX Centuries; (5) Mongolia during the Period of 1911-1921; (6) Mongolia during the Period of Socialism; (7) Mongolia at the Start of the Democratic Movement; (8) Mongolian Traditional Economy: Livelihood, Animal Husbandry, and Agriculture; (9) Mongolia's Traditional Material Culture: Ger (apartment), Board and Lodging; and (10) Mongolia's Traditional Textiles and Decorations (Saruulbuyan 2009: 7). Currently, over 50,000 museum pieces and artifacts on Mongolian history and ethnicity are housed at this museum.

This museum is now conducting its activities at the building of the Museum of Revolution dissolved in 1991. This Museum of Revolution was first built on the occasion of 50th Anniversary of the People's Revolution in 1971. This is the first building in Mongolia built specially for the purpose of a museum. By the decision of the Ministry of Culture, the National History Museum has been renamed the National Museum of Mongolia (Fig. 5).

\section{Changes Taking Place in Museum Collections}

Prior to the 1990s, the main goal of enriching the museum collection was to advocate and publicize those changes that took place in politics, economics, and social life during the period of the socialist revolution, and the achievements during the construction of a socialist society (Baarai and Tumur-Ochir 1975: 8-14). 


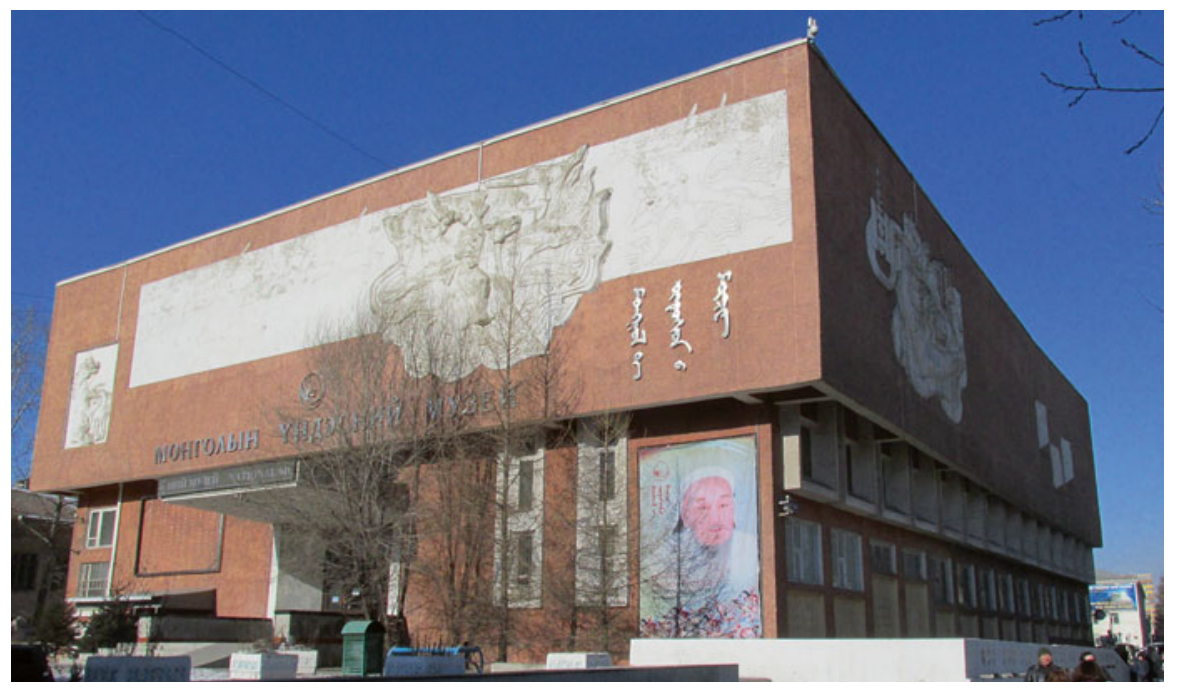

Fig. 5 The National Museum of Mongolia

At that time, work for the collection of museum pieces and artifacts was performed in two forms at the state and local country museums: (1) Employees of the museum would buy items or goods with museum significance in line with predetermined themes of revolution. With that purpose, collection of items with museum significance was organized for a certain period in certain local areas, towns, and settlements; (2) Institutions and private individuals would donate museum items with museum significance (Yadamsuren 1968: 10-16).

Buying of new items and goods with museum significance for the museum collection, particularly in Ulaanbaatar, was organized under the control of the Authority for Museums, Ministry of Culture. The Authority for Museums would buy items and goods with museum significance and they were distributed to individual museums in accordance with themes. It was certain that the Authority for Museums used socialist-communist ideology as guidance when they bought museum items for the museum collections. About $75-80 \%$ of all new items and goods coming into the state and local country museums were items and goods related to the themes of revolution.

Since the dissolution of the Authority for Museums in 1991, the museums have started individually deciding on new items and goods that they buy for their collections. In 1995, by a resolution of the Minister of Culture, the "Rules for Finding Historic and Cultural Items and Conducting their Researches" were approved. With the approval of these "Rules," a "Commission on the Purchase and Pricing of Exhibits" was set up under each museum. Activities under these commissions were supervised by directors of museums, and museum employees were in the composition of the commission. These commissions had the authority to purchase new items for the museum collection. With such a change, a museum could purchase museum items that would fit the main theme of the museum's activities. As mentioned above, 
starting from the middle of the 1920s, wearing the Mongolian national deel (clothing) and decorations made of gold and silver was prohibited. Because self-use was prohibited and even giving them to museums was not welcomed, some private persons used to store articles or items made of silver or gold in their homes. It is now possible for a museum to purchase those goods and items with museum significance that were stored at hands of private persons with the approval of the "Rules for Finding Historic and Cultural Items and Conducting their Researches." It also came to be in the interests of individuals to sell to a museum those items that have lost the value of their earlier utility. Thus, Mongolia's museums started obtaining some items that were previously impossible to acquire due to ideological barriers during socialism.

After the 1990s, another new form of enriching museum collections appeared. In 1995, a resolution of the Minister of Culture approved the "Rules for Conducting Archaeological Researches and Excavation." In accordance with the former Rules, the Ministry of Culture would provide a permit for the undertaking of archaeological studies and performing of archaeological excavations only to professional scientific institutions. By these new Rules, museums with state status such as the National History Museum and the Museum of Natural History were allowed to undertake independent archaeological excavation. In addition, according to the new Rules, archaeological findings were to be transferred to the State Treasury Fund as well as to museum collections. With the approval of the new Rules, the National Museum of Mongolia was able to take part in all archaeological excavations conducted by the Institute of Archeology of the Academy of Sciences of Mongolia. For example, the National History Museum has successfully taken part in a number of archaeological excavations such as Orkhony Khushuu Tsaidam (2005), the ruins of the capital of the Mongolian Empire - Kharakhorum (2008), and Kherlengiin Khuduu Aral (Erdenebat 2012: 211-216). Findings of these excavations were transferred to the collection of the National Museum of Mongolia. In addition, the Museum of Natural History has taken part in fieldwork studies as well as excavations conducted by the Institute of Paleontology of the Mongolian Academy of Sciences. No such possibilities were presented to any museum that was functioning prior to the 1990s in Mongolia.

From the 1990s, the financial capacity for enriching museum collections has significantly declined due to the economic crisis in Mongolia. At this time, owing to financial constraints, museums had a policy of buying few items and only those with great museum significance. Although the financial capacity of museums decreased during this period, museums were continuously enriching their collections. For example, the Zanabazar Museum of Fine Arts bought 700 items that were consistent with its profile of activities over the period last 20 years. About $60 \%$ of these new items the museum bought through its own Commission on the Purchase and Pricing of Exhibits (Uranchimeg 2014: 218). Figure 6 shows how the enrichment of museum exhibits was conducted at the Zanabazar Museum of Fine Arts Gallery. In 1998, there is a temporary decrease in the number of collection because the Museum of Contemporary Art became independent from the Zanabazar Museum of Fine Arts. 


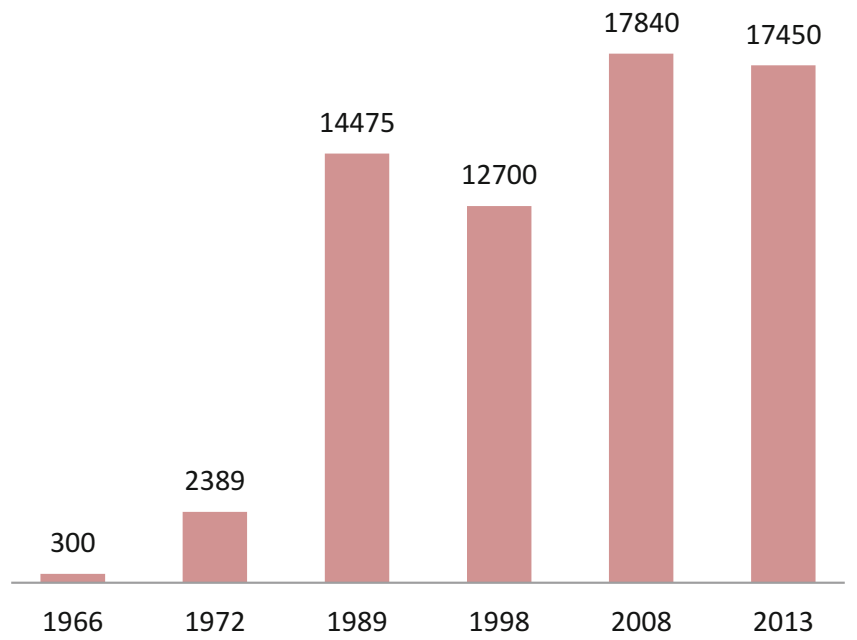

Fig. 6 Collection of the Zanabazar Museum of Fine Arts since 1966

In addition to financial difficulties, there was an additional factor influencing the decrease in new museum items and artifacts being obtained by the state museums. In 1994, a resolution of the Minister of Culture approved the "Rules on Purchase and Exchange of Historical and Cultural Items." With the approval of these Rules, antiques sales started all over the country through antiques shops. Prior to the 1990s, antiques sales were banned in Mongolia. Under a permit issued by the Ministry of Culture, private individuals and companies were entitled to run an antiques business. With the start of antiques sales, private individuals who possessed pieces and items with museum significance have significantly reduced transferring or selling these pieces and items into the possession of state museums. The large discrepancy between the prices offered by museums and those by antiques shops in the purchase of historic and cultural pieces and items has certainly had an impact on the above situation. In addition, with the start of antiques sales, there were apparently many negative activities. Also, it was apparent that there were cases where individuals and companies who had no permit to conduct antiques business from the Ministry of Culture started selling antiques. A chain of illegal international antiques businesses started working in Mongolia. There were cases of selling pieces and items from a museum collection through illegal chains of antique businesses. For example, there was a case of a museum piece that was stored in the collection of the National Museum of Mongolia being sold through a chain of illegal antique businesses. Owing to this, Mongolian legal institutions later established that a total of 13 billion tugrik (according to the exchange rate of that time, the loss was equivalent to USD 13 million) in loss was incurred by the National Museum of Mongolia. This was a single largest organized crime in the modern history of museums. 
Not only were museum pieces and items sold but there were also cases of nonmuseum items having been sold through this chain of illegal businesses. For example, non-legal paleontological excavation was organized in the southern part of Mongolia and a large number of findings from the excavation were sold through a transborder deal. The skeleton of a Tarbosaurus bataar that was found in southern Mongolia and obtained through a transborder purchase was in a New York auction in 2012 and was sold at the auction for about USD 100 million. At the request of the Mongolian side, the auction transaction was voided and a US district court issued a decision to return the Tarbosaurus bataar skeleton to Mongolia. The US court decided to return to Mongolia not only the Tarbosaurus bataar skeleton, but also the skeletons of 22 other dinosaurs that left Mongolia illegally in the 1990s (Tsendsuren 2014: 77-78).

Just recently, the world press and media informed us that a Green Tara created by Undur Gegeen Zanabazar was put up for auction and sold for three million euros. Since 2001, by a decision of the Government of Mongolia, all arts of Undur Gegeen Zanabazar and of his school have been ranked as "Unique and Priceless" historical and cultural memorials. The Ministry of Culture, Sports and Tourism of Mongolia expressed its protest against this auction in Paris although the organizers of this auction sale did not receive a complaint from the Government of Mongolia. Currently, it is not known when this artwork of Zanabazar left Mongolia. By now, however, there are no conditions under which similar crimes could possibly be repeated in the future.

As I have mentioned above, starting in the middle of the 1920s, Mongolian historical and cultural memorial items illegally left Mongolia to go abroad. Starting only in the 1990s did the Ministry of Culture raise the issue of returning to Mongolia those historical and cultural objects that left the country illegally. However, implementation of this issue has yet to be started. There are a variety of reasons, both dependent and independent, on the Mongolian side. First of all, the Mongolian audience expresses the opinion that the raising this issue is not well prepared when Mongolia's museums are not well organized and the conditions for the secure preservation and conservation of museum pieces do not meet the required standards.

Amongst new items that have replenished Mongolia's museum collections since the 1990s, the percentage of items and museum pieces with themes of revolution has been significantly reduced. Although no statistical data are available in respect of the percentage of newly arrived museum items associated with revolutionary themes, there is a belief that it has been significantly reduced. In this connection, it must be said that no similar museum statistics are available in Mongolia. With the dissolution of museums such as the State Central Museum, Museum of Revolution, and Lenin Museum, which had conducted their museum activities under revolutionary themes, it is evident that this greatly influenced the decrease in the percentage of revolutionary content amongst the total number of newly arrived items in the scale of the entire country. 


\section{Issues and New Trends in Respect of Registration and Documentation of Museum Collections}

Prior to the 1990s, the proper registration and documentation of museum collections in Mongolia was a neglected task. During that period, a registration card was filed for a museum collection piece. The content of the registration card was approved by the Ministry of Culture and it was required for all museums with state or local country status. The registration card contained a photo of the museum piece or item, name, purpose, reason for being kept in the museum, and its scientific description. However, there was no information regarding size, form of the museum piece, or materials that it was made of. However, most of the museums did not file registration cards at all and if did do so, they did not do it well. There are many reasons for this. A major reason is that the museum itself did not conduct any research work and museum employees were non-professionals. Therefore, among the museum pieces, there were many indeterminate questions that not just anyone could answer easily: what it is, what it is called, who, when, and for what purpose was it made, and when and why it entered the collection.

Starting in the 1990s, innovations have started in the ways of registration and documentation of museum collection items. In 1994, the "Law on Conservation of Historical and Cultural Artifacts" was approved. The Law had a provision for creating a "State Registration and Information Database on Historical and Cultural Artifacts." Following this, the "Rules for the Creation of State Registration and Information Database on Historical and Cultural Artifacts" were approved by a resolution of the Minister of Culture. With the approval of the Rules, innovation of registration cards for museum collections has started all over the country. The Ministry of Culture has approved the State Registration Card of Historical and Cultural Artifacts of Mongolia (Form No. 1) and has ordered all the museums of Mongolia to compile the card. After that, the Ministry of Culture decide to create the Center of Cultural Heritage by expanding the composition and structure of "Reconstruction Artistry for Museum Exhibits." Within the newly established Center of Culture Heritage, it has been decided to set up a State Registration and Information Database. At the beginning, the registration card for museum collections was compiled in two copies: one to be retained by the museum itself and the other to be sent to the newly established Center of Culture Heritage. However, this work has encountered a number of difficulties and is progressing quite slowly. Starting in 2005, Mongolia's government began implementing the "Program on Digitalized Storage of National Cultural Heritage Information." Within the frame of this program, based on the registration card for museum collections compiled for all museums, a software program called $\mathrm{RCH}$ or Registration of Cultural Heritage 1.0 was designed. State and local country museums have been provided with the $\mathrm{RCH}$ or Registration of Cultural Heritage software program along with computers and the other required technical equipment. A total of 38 museums with local country status that conduct their activities in 21 aimags have been included in this project. Starting in 2010, a revised version of the $\mathrm{RCH} 2.0$ software program was implemented into practice. 


\section{Issues for the Preservation and Conservation of Museum Items}

One of the main functions for any museum is the preservation and conservation of museum collections employing scientific methods and methodology. About $90 \%$ of all museums functioning prior to the 1990s conducted their activities in buildings that were not specially designed for museum purposes. Amongst the museums with state status that were functioning in Ulaanbaatar at that time, the Museum of Revolution functioned in a special museum building. Another museum functioning in a special museum building was the Lenin Museum. However, this museum did not hold state status but was functioning under the MPRP - the governing political party at that moment in time. With respect to local country museums, the situation was no different to that above. Although there were some cases of local administration building new buildings for their local country museums, these cases were only very few (Lkhagvasuren and Konagaya 2007: 65). For museums not located in specially designed museum buildings, it is clear that the ways of preservation and conservation do not meet the conditions and requirements of safety standards for specific museum pieces and items. For museums of that period, the following general flaws were evident:

1. Rooms for museum collections were small, and had no shelves or special boxes designed for safe storage of museum pieces.

2. No registration of museum pieces was done in respect of themes or materials and all museum pieces were stored all along together.

3. Temperature, relative humidity, and air content of rooms, where museum pieces were stored, were not controlled or regulated at all.

4. Insecticidal procedures for rooms in which museum pieces were stored were hardly ever done.

5. Museums never conducted any reconstruction activities for museum pieces and items.

These obligatory jobs that should be conducted in the storage rooms of museum pieces were almost never done; as result, occurrences of damage, color loss, and infection with insects were quite commonplace. Since the 1990s, the first steps were taken to fix the above situation. The Ministry of Culture approved a number of documents: "Bylaw for Museum Collections of Mongolia" in 2005, "Requirements for Museum Affairs: The Standard of Mongolia" in 2006, "Bylaw for Local Country Museums" in 2009, and "Instructions for Registration and Documentation of Museum Collections" in 2012. The main goal of all of these documents was to improve the conditions of conservation of museum pieces and elaborate the registration documents of museum pieces. Before this time, Mongolian museums did not classify the museum pieces by materials from which the given museum pieces were made; rather, they classified museum items as "made of soft material" and "made of hard material." After the issuance of the above documents, the largest state museums start classifying collections of their museums in accordance with themes. For 
example, collections of the National History Museum were classified into three main themes: (1) Collection of Precious Items (items made of gold and silver and items with religious themes); (2) Collection of History and Archaeology; and (3) Collection of Ethnology. Items under each collection started being stored separately from each other. After classifying the museum items in accordance with the corresponding themes, within each collection, items started being classified in accordance with the materials from which they were made. For example, items made of hard materials were classified as items made of metal, stone, and wood; each of them were separated and started being stored separately. In addition, items made of soft materials such as cotton started being considered as one group and stored separately. Metallic shelves and wooden boxes were placed to store museum pieces individually. Measures were taken to protect items placed on the shelves from dust (for instance, some items were covered by a sheet of cotton). Most museum pieces were placed inside carton boxes and put on metallic shelves. In addition, in each collection room, each metallic and wooden shelf inside the rooms was numbered. After this numbering, measures were put in place to easily understand and locate which items are kept in which rooms and on which shelves. Lately, there is the apparent trend that the materials of museum pieces are classified as being made of "organic-quality" and "non-organic-quality" materials. UNESCO projects have been implemented at some museums such as the Zanabazar Museum of Fine Arts and conditions of storage of museum pieces have significantly improved (Uranchimeg 2014: 218-228). Some museums have started utilizing room airconditioning and room air relative humidity regulation equipment that were produced in such countries as Germany. However, insecticidal procedures are lagging rather far behind. In accordance with the "Law on Conservation of Historical and Cultural Artifacts," which was approved in 1994, historical and cultural artifacts were graded as "Unique and Priceless," "Precious," and "Ordinary" (Enkhbayar 1996: 83). Along with this law, the "Rules of the Professional Council for Determination of Grade and Price of Historic and Cultural Memorial Items" were approved. According to these Rules, the Professional Council for Determination of Grade and Price of Historic and Cultural Memorial Items was set up. The composition of this Council consisted of specialists from the Institute of History, Institute of Archaeology, Institute of Geology, Institute for Culture and Arts, Archives Administration, and Center for Cultural Heritage of Mongolia. After the approval of the "Law on Conservation of Historical and Cultural Artifacts," museums with state or local country status reviewed all of their museum collections and determined each of their museum items in accordance with grades of "Unique and Priceless," "Precious," and "Ordinary" and started paying due attention to the storage conditions of those items. Currently, there are 250 museum pieces graded as "Unique and Priceless" that are stored at the museums with state or local country status. Mongolia's museums are conducting quite a lot of work for the proper preservation and conservation of museum pieces but this work has still not yet reached the required standard. 


\section{International Cooperation of Museums and New Trends}

Since the 1990s, Mongolia's museum institutions have been actively engaged in cooperation with international museum institutions. Relations that were active only with museums of former socialist countries, particularly those of Eastern European and those of the former Soviet Union, have now been expanded further and new opportunities have opened to establish ties with museums of many other nations. During this time, the Mongolian Museums Union was established to become a member of international museum institutions such as ICOM and ICCROM. Opportunities opened for Mongolia's museum employees to regularly take part in international seminars and meetings organized by these international museum institutions. In addition, opportunities have opened for Mongolia's museum employees to regularly take part in training at museums in Germany, Denmark, Finland, and the USA to upgrade their professional skills and qualifications and learn from their experience.

Since September 1994, Mongolian museum associates have regularly taken part in the international training courses on museology that take place at the National Museum of Ethnology in Osaka (hereafter referred as Minpaku) under the financial support of JICA - the Japan International Cooperation Agency. Currently, over ten specialists from Mongolian museums have participated in the activities of this seminar. They are (1) D. Tsedmaa- Ministry of Education, Culture, and Science (MECS) (1994); (2) I. Lkhagvasuren-National History Museum (1994); (3) Z. Oyunbileg-MECS (1999); (4) D. Enkhtsetseg-Fine Arts gallery (2002); (5) Ch. Natsagnyam-Kharakhorum Museum (2009); (6) B. Ulziibayar-Mongolian Theatre Arts Museum (2009); (7) A. Yanjiv-Culture Arts Committee (2010); (8) J. Myandas-Natural History Museum (2010); (9) Ts. Oyunkhishig-National Museum (2011); (10) D. Narantuya-Culture Heritage Center (2011); and (11) G. Yalalt-Fine Arts Gallery (2011). Most of the specialists taking part in museum training are currently working in this field and it is gratifying to note that they continue adding their contributions to museum affairs and advocating the development of proper preservation and conservation of museum items. In addition, four training seminars have been organized for museum employees in Ulaanbaatar. They are as follows:

- Seminar on "Methodology of Preservation and Conservation of Historical and Cultural Memorials," from April 1 to April 7, 1996.

- Seminar on "Classification and Generalization of Museum Pieces," from April 1 to April 7, 1997.

- Seminar on "Registration of Museum Collections and Its Significance," from April 1 to April 8, 1998.

- Seminar on "Method of Using Digital Technology in the Creation of a Registration and Information Database for Historical and Cultural Memorials and Its Significance," from July 2 to 3, 2000. 
These seminars, which had important implications and significance for the upgrading of the professional skills of Mongolian museum employees, were led and conducted by Professor T. Morita from the National Museum of Ethnology, Japan.

Since the 1990s, Mongolia's museums have actively engaged in the organization of international exhibitions abroad. Formerly, organization of international exhibitions was restricted to only former socialist countries, but from this period, this restriction was further lifted so that organization of exhibitions on Mongolian history and ethnicity as well as on paleontological themes can take place in many countries of the world. The first large-scale exhibition on Mongolian history and ethnology opened in Munich, Germany in 1989. Since then, over ten exhibitions on Mongolian history and ethnology opened in a number of countries such as the USA, France, and Japan. In addition, a thematic exhibition on Mongolian dinosaurs was successfully organized in many countries of the world.

\section{Conclusions}

The first museum in Mongolia started its activities on December 25, 1924. Starting in the middle of the 1920s, Mongolian cultural heritage, created over many generations, has been treated from the angle of communist-socialist ideology as belonging to the culture of the exploiter class and the culture of the exploited class. Until the 1990s, the museum affairs of Mongolia were dictated and dominated by communistsocialist ideology and advocacy of achievements in the construction of the socialist revolution and praising of a socialist-communist society - the rightful future of humanity-were the main guidelines for the museum activities of Mongolia.

The democratic movement started in the 1990s and the first steps were taken to bring about larger changes in the field of culture, particularly for the protection and conservation of historic and cultural heritage as well as for the museum affairs of Mongolia. First of all, museum activities were to find historical and cultural objects, register such objects into the museum collections, organize work for the preservation and conservation of museum objects, draw these objects into the cycle of scientific research, and promote public advocacy of museum goals. Although Mongolia's museums have made quite an achievement in the implementation of the above goals, there are still many goals that need to be accomplished.

Open Access This chapter is distributed under the terms of the Creative Commons AttributionNonCommercial 4.0 International License (http://creativecommons.org/licenses/by-nc/4.0/), which permits any noncommercial use, duplication, adaptation, distribution and reproduction in any medium or format, as long as you give appropriate credit to the original author(s) and the source, provide a link to the Creative Commons license and indicate if changes were made.

The images or other third party material in this chapter are included in the work's Creative Commons license, unless indicated otherwise in the credit line; if such material is not included in the work's Creative Commons license and the respective action is not permitted by statutory regulation, users will need to obtain permission from the license holder to duplicate, adapt or reproduce the material. 


\section{References}

Baarai, S., and S. Tumur-Ochir. 1975. History of origin and development of the State Central Museum. 5(3): 8-14. (In Mongolian).

Burnee, U. 1994. National History Museum of Contemporary Mongolia. Ulaanbaatar: State Publishing House. (In Mongolian).

Enkhbayar, N. (ed.). 1996. Culture and arts under new conditions. Ulaanbaatar: State Publishing House. (In Mongolian).

Erdenebat, U. 2012. Basis of archeology and research methods. Ulaanbaatar: Soyombo Printing Co. Ltd.. (In Mongolian).

Konagaya, Y., and I. Lkhagvasuren. 2014. Studies on material culture of Mongols - Nomads. In Cultural Heritage of Mongols, ed. S. Chuluun, 76-102. Ulaanbaatar: Admon Printing Co. Ltd.. (In Russian).

Konagaya, Y., S. Bayaraa, and I. Lkhagvasuren. eds. 2007. A.D.Simukov, Works about Mongolia and for Mongolia. Vol. 1 (SER 66). Osaka: National Museum of Ethnology. (In Russian).

Konagaya, Y., S. Bayaraa, and I. Lkhagvasuren. eds. 2008. A.D.Simukov, Works about Mongolia and for Mongolia. Vol. 3 (SER 75). Osaka: National Museum of Ethnology. (In Russian).

Lkhagvasuren, I., and Yuki Konagaya (eds.). 2007. Tsogt-Ochiriin Lookhuuz (SER 72). Osaka: National Museum of Ethnology. (In Japanese and Mongolian).

Lkhamsuren, B. (ed.). 1985. Brief history of Mongolian people's revolutionary party. Ulaanbaatar: State Publishing House. (In Mongolian).

Myandas, J. 2014. Origin of the Museum of Natural History. In New Horizons in Asian Museums and Museology, eds. Sonoda, N., Y. Konagaya, and I. Lkhagvasuren, 93-97 and 285-291. Ulaanbaatar: Admon Printing Co. Ltd. (In Japanese and Mongolian).

Saruulbuyan, J. (ed.). 2009. National Museum of Mongolia. Ulaanbaatar: Munkhiinuseg Printing Co. Ltd.. (In English).

Sereeter, C.H., K.H. Tserev, and B. Chadraa, eds. 2003. History of Academy of Sciences of Mongolia. Ulaanbaatar: Bembisan Printing Co. Ltd. (In Mongolian).

Tsendsuren. T.S. ed. 2014. History of Mongolian Museums. Ulaanbaatar: Admon Printing Co. Ltd. (In Mongolian).

Uranchimeg, D. 2014. Preservation of the collection at Zanabazar Art Museum. In New Horizons in Asian Museums and Museology, eds. Sonoda, N., Y. Konagaya, and I. Lkhagvasuren, 39-48 and 215-229. Ulaanbaatar: Admon Printing Co. Ltd. (In Japanese and Mongolian).

Yadamsuren, P. 1968. Mongolian museum studies. Museum Studies 4(5): 10-16. (In Mongolian). 